\title{
Impact of NPK Bio-Fertilization on Some Growth Pomegranate of Manfaloty and Wonderful Pomegranate Transplants
}

\author{
Rehab. E. B. El-Kholy ${ }^{1}$, A. R. Atawia ${ }^{1}$, T.A.M El-Akkad ${ }^{2}$ and S. F. El-Gioushy ${ }^{1}$ \\ 1. Horticulture department, Faculty of agriculture, Benha University, Egypt. \\ 2. Genetic and genetic engineering department, Faculty of agriculture, Benha University, Egypt. \\ *- Corresponding author: rehaballkholy7@yahoo.com
}

\begin{abstract}
This study was conducted throughout the two successive seasons of 2017 and 2018 at Fruit Nursery of Horticulture Department, Faculty of Agriculture at Moshtohor, Benha University Qalyubeia Governorate, Egypt., to study the impact of NPK bio fertilization application on different growth parameters of Manfaloty and Wonderful pomegranate transplants at one-year- old. The eight treatments involved in this study were summarized as follows: T1-recommended doses (RD), T2-RD NPK mineral fertilizers + Soil application of Nitrobene at $5 \mathrm{ml} /$ transplant,T3-RD NPK mineral fertilizers + Soil application of Nitrobene at $10 \mathrm{ml} /$ transplant, T4-RD NPK mineral fertilizers + Soil application of Phosphorene at $5 \mathrm{ml} /$ transplant,T5-RD NPK mineral fertilizers + Soil application of Phosphorene at $10 \mathrm{ml} /$ transplant, T6 - RD NPK mineral fertilizers + Soil application of Potasene at $5 \mathrm{ml} /$ transplant,T7- RD NPK mineral fertilizers + Soil application of Potasene at $10 \mathrm{ml} /$ transplant and T8 RD NPK mineral fertilizers + Nitrobene at $5 \mathrm{ml}+$ Phosphorene at $5 \mathrm{ml} /+$ Potasene at $5 \mathrm{ml} /$ transplant.The result indicated that, application of T8 (RD NPK mineral fertilizers + Nitrobene at $5 \mathrm{ml}+$ Phosphorene at $5 \mathrm{ml} /$ + Potasene at $5 \mathrm{ml} /$ transplant) caused a significant increasing in the rate of length, diameter, number of leaves, leaf area,transplant leaves area, fresh and dry weights.Moreover, T3 (RD NPK mineral fertilizers + Soil application of Nitrobene at $10 \mathrm{ml} /$ transplant)ranked statistically second in this concern. On the contrary, the least values of the abovementioned parameters were usually in concomitant to $\mathrm{T}_{1}$ - Control (recommended dose) which ranked statistically last during both seasons of study.
\end{abstract}

Keywords: Manfaloty, wonderful, pomegranate, NPK-bio fertilizers, Transplants and growth

\section{Introduction}

Pomegranate Punica granatum L., belongs to the Punicaceae family and is one of the oldest known edible fruits. It has been cultivated extensively in Mediterranean countries. The fruit is consumed fresh, or it can be processed into juice, syrup, jams, or wine. The edible part of the fruit contains considerable amounts of acids, sugars, vitamins, polysaccharides, polyphenols and important minerals.

The pomegranate tree grows well in a wide range of climatic conditions, but the most satisfactory areas are interior valleys of California, Arizona and Northern Mexico, where hot dry summer mature fruit of highest quality. It is a desert plant, but also grows well under high humidity as in high Himalayas, but shipping and keeping qualities are declared by humid conditions. This plant well succeeds as for as the 35 the degree latitude north but during extreme cold periods, the plant are sometimes injured by cold. The trees withstand a temperature of $10 \mathrm{~F}$ to $15 \mathrm{~F}$, a rather large amount of summer heat is required to ripen the fruits (The Standard Cyclopedia of Horticulture, 1970).

The pomegranate has reversal nutritive, industrial, medicinal values and some pharmacological properties. Extracts of different parts of pomegranate plants and fruits have hypotensive (causing low blood pressure). Antispasmodic (having the power to prevent or relieve spasms or convulsion) and anthelmintic properties (expelling or destroying parasitic warms). The seed oil was also shown to possess oestrogenic (var. of Estrogen) activity but was devoid of any and ergenic (male parthenogenesis).

The pomegranate area in Egypt (13609) feddans, according to annual of the Ministry of Agriculture Anonymous (2011).

Wonderful pomegranate is late cultivar with high yield, large fruit, rich red aril, high juice, and good palatability (Palou et al., 2007). Wonderful is currently one of the most desired planted pomegranate cultivars in Egypt since it offers best balance combination yield and quality (Abd-elghany et al., 2012).

There are many factors face the growers to improve and maximize their productivity for example, propagation, fertilization, irrigation and other horticultural practices.

Most fruit seedlings are known to be slow growing plants, since they develop few lateral shoots and roots. Such growth habit of these seedlings poses a major problem to nurserymen, since the loss of a large portion of the plant root system in the retransplanting process coupled with the slow vegetative growth in the first seasons account for the long time required to produce a standard nursery 
seedlings (Brison, 1974). Furthermore, a major comparison for the low of soil fertility was the extensive use of chemical fertilizers and gradually it became an expensive item in orchard management. Moreover, fruit growers are faced by the hazards of increased use of chemical in agriculture production which result in environmental pollution.

Fertilization is one of the important management tools in increasing growth and crop yield, especially with nitrogen. Nitrogen $(\mathrm{N})$ is known to be one of the most major elements for plant nutrition and development. It plays an important role as a constituent of all proteins, nucleic acids and enzymes (Nijjar, 1985).

The use of bio-fertilizers in enhancing plant growth and yield has gained momentum in recent years because of higher cost and hazardous effect of chemical fertilizers. Nitrogen-fixing bacteria and arbuscular mycorrhizal fungi were found to enhance the growth and production of various fruit trees significantly (Khanizadeh et al., 1995), besides improving the microbiological activity in the rhizosphere (Aseriet al., 2008). Bio-fertilizer improves growth and fruit quality of pomegranate (Abo-Taleb, Safia et al., 1999, Wadee, 2007 and Aseri et al., 2008).

Bio-fertilizers are mainly consisted of beneficial microorganisms that can release nutrients from rock and plant residues in the soil and make them available for economical crops. They are of the most importance for plant production and soil fertility as they improve the biological, physical and chemical properties of the soil. Moreover, biological fertilization plays an important role in increasing the yield and fruit quality of citrus (Subba Rao et al., 1993; Subba Rao, 1984).

Thus, the main objective of this investigation was directed towards improving Manfaloty and wonderful pomegranate transplants vegetative growth and nutritional Status by using NPK bio fertilizers.

\section{Materials and Methods}

This study was carried out during the two successive seasons of 2017 and 2018 on uniform in vigor transplants of Manfaloty and Wonderful pomegranate (Punica granatum L.) cultivars. This experiment aimed to know more knowledge about the effect of bio-fertilizer on growth and nutrients status of Manfaloty and Wonderful pomegranate transplants at the nursery of the Faculty of Agriculture, Benha University. Uniform and healthy one-year- old seedlings of Manfalouty and Wonderful pomegranate cultivarswere theplant material used in this study. In both seasons of study and during the second week of February, these seedlings were transplanted individually each in clay pot of $25 \mathrm{~cm}$. in diameter that previously had been filled with specific weight of media consisting of clay and sand at equal proportion (by volume).

Before the experiments had been conducted in the first season, both mechanical and chemical analysis were done shown in Table $1(\mathrm{a} \& \mathrm{~b})$ according to the methods described by Jackson and Ulrich, (1967) and A. O. A. C., (1985).

Table (1-a): Physical properties of soil (\%):

\begin{tabular}{lll}
\hline Partial distribution & & \\
\hline Total sand & Silt & Clay \\
60.00 & 10.00 & 30 \\
\hline
\end{tabular}

Table (1-b): Chemical properties of soil:

\begin{tabular}{|c|c|c|c|c|c|c|c|c|c|c|}
\hline \multicolumn{4}{|c|}{ Soluble cations $\mathrm{mg} / \mathrm{L}$} & \multicolumn{4}{|c|}{ Soluble anions meg $/ \mathrm{L}$} & \multirow{2}{*}{$\begin{array}{l}\text { Ca Co3 } \\
1.30\end{array}$} & \multirow{2}{*}{$\begin{array}{l}\text { PH } \\
8.72\end{array}$} & \multirow{2}{*}{$\begin{array}{l}\text { EC } \\
1.90\end{array}$} \\
\hline $\begin{array}{l}\mathbf{M g}^{++} \\
2.10\end{array}$ & $\begin{array}{l}{ }^{++} \mathrm{Ca} \\
8.80\end{array}$ & $\begin{array}{l}\mathrm{K}^{+} \\
0.60\end{array}$ & $\begin{array}{l}\mathrm{Na}^{+} \\
7.70\end{array}$ & $\begin{array}{l}\mathrm{HCO}^{-} \\
3.00\end{array}$ & $\mathrm{CO}_{3--}^{--}$ & $\begin{array}{l}\text { SO4-" } \\
9.20\end{array}$ & $\begin{array}{l}\mathrm{Cl}^{-} \\
6.90\end{array}$ & & & \\
\hline
\end{tabular}

The bio-fertilizers (BF) which used in this study were produced by soil microbiology unit, Ein Shams university. Nitrobene application as an additional $\mathrm{N}$ bio*fertilization, while Phosphorene additional $\mathrm{P}$ bio-fertilization as well as Potasene additional $\mathrm{K}$ biofertilization to the seedlings. This experiment involved seven treatments:

○ T1- Mineral fertilizers: NPK fertilization program, (recommended doses ) as control was added from $40 \mathrm{~g}$ from ammonium sulphate, $20 \mathrm{~g}$ from superphosphate and $10 \mathrm{~g}$ potassium sulphate were annually added per plant monthly from April to July.

oT2- RD NPK mineral fertilizers + Soil application of Nitrobene at $5 \mathrm{ml} /$ transplant.
oT3- RD NPK mineral fertilizers + Soil application of Nitrobene at $10 \mathrm{ml} /$ transplant.

oT4- RD NPK mineral fertilizers + Soil application of Phosphorene at $5 \mathrm{ml} /$ transplant.

oT5- RD NPK mineral fertilizers + Soil application of Phosphorene at $10 \mathrm{ml} /$ transplant.

oT6- RD NPK mineral fertilizers + Soil application of Potasene at $5 \mathrm{ml} /$ transplant.

oT7- RD NPK mineral fertilizers + Soil application of Potasene at $10 \mathrm{ml} /$ transplant.

oT8- RD NPK mineral fertilizers + Nitrobene at 5 $\mathrm{ml}+$ Phosphorene at $5 \mathrm{ml} /+$ Potasene at $5 \mathrm{ml} /$ transplant. 
Application time:

Anyhow,Bio-fertilizers (Nitrobene + Phosphorene + Potasene) were applied twice in April and May.

Experimental layout:

The complete randomized block design with three replications was used for arranging the differential investigated treatments. Every replicate was represented in each of the aforesaid three plants. The response of Pomegranate transplants to differential treatments of the experiment was investigated throw determining of the following measurements:

- Vegetative growth measurements:

On last week of August during both seasons as the experiment wasended, the effect of different treatments on some vegetative growth measurements wereevaluated by the following growth parameters during both seasons as follows:

\section{Stem height $(\mathrm{cm})$.}

Net increase in plant height $=$ plant height in the end of August- initial plant height on the first of April.

Increment percentage in stem height was

estimated as follows:

Final stem height - Initial stem height

Initial stem height

X100

2. Stem diameter (cm).

Net increase in stem diameter $=$ Stem diameter in the end of August - Initial stem diameter in the first of April.

Increment percentage in stem diameter was estimated as follows:

Final stem diameter- Initial stem diameter

X100

Initial stem diameter

3. Number of lateral shoots / transplant

4. Number of main branches / transplant

5. Leaves dry weight

6. Leaves fresh weight

7. Leaf area:

Five mature leaves were taken from the middle of shoots for each transplant to measure the leaf area $\left(\mathrm{cm}^{2}\right)$ according to the following equation.

The average leaf area $\left(\mathrm{cm}^{2}\right)=\frac{\text { Leaves weight }(\mathrm{g})}{\text { Sections weight }(\mathrm{g})} \times 2$ The method was described by Motskobili (1984) and followed by Mohsenet al., (1987).

- $\quad$ Root growth meagerments

9. Root weight

10. Root lengh

- Fresh andt dry weights (g) of plant organs (leavesand stem) root weight $(\mathrm{g})$ root length $(\mathrm{cm})$.

\section{Statistical Analysis:}

All data obtained during both seasons were subjected to analysis of variance and significant differences among means were determined according to (Snedecor and Cocharn, 1977). In addition, significant differences among means were differentiated according to the Duncan's, multiple range (Duncan, 1955). Where capital letters were used for distinguishing means of different treatments for each investigated characteristic.

\section{Results and Discussion}

1- Effect of NPK bio- fertilizers on increment percentage of stem height $(\mathrm{cm})$ and increment percentage stem diameter $(\mathrm{cm})$ of Manfaloty and wonderful pomegranate transplants:

Concerning the response of the increment percentage of stem height $(\mathrm{cm})$ and increment percentage stem diameter $(\mathrm{cm})$ of Manfaloty and wonderful pomegranate transplants to the differential investigated treatments; Table (2) shows a considerable variation in this respect. Herein, the highest number of values were significantly coupled with the transplants subjected to $\mathrm{T}_{8}$-RD NPK mineral fertilizers + Nitrobene at $5 \mathrm{ml}+$ Phosphorene at $5 \mathrm{ml}$ + Potasene at $5 \mathrm{ml} /$ transplant. Moreover, $\mathrm{T}_{3^{-}}(\mathrm{RD}$ NPK mineral fertilizers + Soil application of Nitrobene at $10 \mathrm{ml} /$ transplant ranked statistically $2^{\text {nd }}$ on its efficiency. On the contrary, the least values of the abovementioned parameters were usually in concomitant to $\mathrm{T}_{1}$ - Control (recommended dose) which ranked statistically last during both seasons of study.Besides, five other investigated were in between the previously mentioned two extremes. Such trend was true during two experimental seasons and with both cultivars.

The present results regarding the great beneficence of NPK bio-fertilizers application on stimulating different growth parameters goes in parallel line with those found by several investigators i.e., (Osman and Abd El-Rhman, 2010) on fig tree, (EL-Gioushy, 2016) on young Manfalouty Pomegranate trees, (El-Badawy and Ali, Maha, 2019) on Banana Grande Naine Cultivar .

2 -Effect of NPK bio- fertilizers on number of lateral shoot number of main branches/ transplants and number of main branches/ transplantof Manfalotywonderful pomegranate transplants:

Table (3) displays obviously that all investigated treatments of using bio-fertilizers resulted significantly in increasing total number of lateral shoot number of main branches/ transplants of number of main branches/ transplant of Manfaloty and wonderful pomegranate transplants. However, T8-RD NPK mineral fertilizers + Nitrobene at $5 \mathrm{ml}$ + Phosphorene at $5 \mathrm{ml}+$ Potasene at $5 \mathrm{ml} /$ transplant were statistically the superior with both Manfaloty and wonderful pomegranate transplants and showed the highest total values during 2017\& 2018 experimental seasons. However, T2 and T3 showed 
significantly the same effectiveness in this concern with Manfaloty pomegranate transplants but with Wonderful pomegranate transplantsT6 showed significantly the same effectiveness in this concern in generally, all the above mentioned treatments ranked statistically the superior with both cultivars during two experimental seasons. On the contrary, the least values of the abovementioned parameters were usually in concomitant to $\mathrm{T}_{1}$ - Control (recommended dose) which ranked statistically last during both seasons of study. Besides, the other investigated were in between the previously mentioned two extremes.

Table 2. Effect of NPK bio- fertilizers on increment percentage of stem height $(\mathrm{cm})$ and increment percentage stem diameter $(\mathrm{cm})$ during 2017and 2018 experimental seasons.

\begin{tabular}{|c|c|c|c|c|}
\hline \multirow{3}{*}{ Parameters } & \multicolumn{4}{|c|}{ A. Manfaloty pomegranate transplants } \\
\hline & \multicolumn{2}{|c|}{ increment percentage of stem } & \multicolumn{2}{|c|}{$\begin{array}{c}\text { increment percentage stem } \\
\text { diameter }(\mathrm{cm})\end{array}$} \\
\hline & 2017 & 2018 & 2017 & 2018 \\
\hline T1. Control (recommended dose) & $43.33 \mathrm{e}$ & $31.667 \mathrm{e}$ & $68.00 \mathrm{f}$ & $66.33 \mathrm{c}$ \\
\hline T2. RD+5ml of Nitrobin & $59.63 \mathrm{~d}$ & $31.633 \mathrm{e}$ & $79.33 \mathrm{~cd}$ & $77.00 \mathrm{a}$ \\
\hline T3. RD+10ml of Nitrobin & $63.0 \mathrm{ab}$ & $48.833 \mathrm{~b}$ & $77.33 \mathrm{de}$ & $78.667 \mathrm{a}$ \\
\hline T4. RD+5ml of Phosphorene & $64.73 \mathrm{ab}$ & $41.167 \mathrm{~d}$ & $74.567 \mathrm{e}$ & $79.33 \mathrm{a}$ \\
\hline T5. RD+10ml of Phosphorene & $61.667 \mathrm{bcd}$ & $41.500 \mathrm{~d}$ & $81.330 \mathrm{bc}$ & $72.000 \mathrm{~b}$ \\
\hline T6. RD+ $5 \mathrm{ml}$ of Potasane & $60.232 \mathrm{~cd}$ & $46.433 \mathrm{c}$ & $75.330 \mathrm{e}$ & $72.330 \mathrm{~b}$ \\
\hline T7. RD+10ml of Potasane & $60.233 \mathrm{~cd}$ & $40.330 \mathrm{~d}$ & $84.667 \mathrm{ab}$ & $70.000 \mathrm{bc}$ \\
\hline T8. RD+ 5ml Nitrobin $+5 \mathrm{ml}$ & $66.200 \mathrm{a}$ & $52.500 \mathrm{a}$ & $86.330 \mathrm{a}$ & $81.000 \mathrm{a}$ \\
\hline \multicolumn{5}{|l|}{ Phosphorene $+5 \mathrm{ml}$ of Potasene } \\
\hline \multicolumn{5}{|c|}{ B. Wonderful pomegranate transplants } \\
\hline \multirow[t]{3}{*}{ Parameters } & \multirow{2}{*}{\multicolumn{2}{|c|}{$\begin{array}{c}\text { increment percentage of stem } \\
\text { diameter }(\mathrm{cm})\end{array}$}} & \multirow{2}{*}{\multicolumn{2}{|c|}{$\begin{array}{c}\text { increment percentage stem } \\
\text { height }(\mathrm{cm})\end{array}$}} \\
\hline & & & & \\
\hline & & & & \\
\hline T1. Control (recommended dose) & $42.433 \mathrm{~d}$ & $29.300 \mathrm{~h}$ & $94.000 \mathrm{~d}$ & $100.000 \mathrm{e}$ \\
\hline T2. RD+5ml of Nitrobin & $81.667 \mathrm{~b}$ & $60.300 \mathrm{~b}$ & $114.570 \mathrm{a}$ & $109.330 \mathrm{ab}$ \\
\hline T3. RD+10ml of Nitrobin & $80.000 \mathrm{~b}$ & $67.100 \mathrm{a}$ & $112.670 \mathrm{a}$ & $113.000 \mathrm{a}$ \\
\hline T4. RD $+5 \mathrm{ml}$ of Phosphorene & $79.330 \mathrm{~b}$ & $49.000 \mathrm{~d}$ & $97.330 \mathrm{~cd}$ & $108.000 \mathrm{bc}$ \\
\hline T5. RD+10ml of Phosphorene & $88.330 \mathrm{a}$ & $35.533 \mathrm{~g}$ & $104.670 \mathrm{~b}$ & $100.670 \mathrm{de}$ \\
\hline T6. RD+ $5 \mathrm{ml}$ of Potasane & $57.667 \mathrm{c}$ & $57.200 \mathrm{c}$ & $97.330 \mathrm{~cd}$ & $106.330 \mathrm{bc}$ \\
\hline T7. RD+10ml of Potasane & $54.933 \mathrm{c}$ & $42.367 \mathrm{f}$ & $103.000 \mathrm{bc}$ & $103.670 \mathrm{cde}$ \\
\hline $\begin{array}{l}\text { T8. RD+ 5ml Nitrobin+5ml } \\
\text { Phosnhorene+5ml of Potasene }\end{array}$ & $88.700 \mathrm{a}$ & $46.200 \mathrm{e}$ & $118.000 \mathrm{a}$ & $105.000 \mathrm{bcd}$ \\
\hline
\end{tabular}

Means followed by the same letter/s within each column did not significantly differ at $5 \%$ level.

On the other hand, the noticeable positive effect of the investigated nutritive amendments may be attributed to the additional $\mathrm{N}$ source. Anyhow, the present results are in general in accordance with those previously found by Ebrahiem and Mohamed (2000) on Balady mandarin, El-Sayed , (2005) on Washington navel orange Cv., Osman and Abd ElRahman, (2010) on Fig trees, Zayan et al., (2016) on Washington Navel Orange Trees and ELGioushy et al., (2018) on Fagri Kalan Mango Trees, 3 -Effect of NPK bio- fertilizers on leaves fresh and dry weight (g) of Manfaloty and wonderful pomegranate transplants:

In this regard leaves fresh and dry weight of Manfaloty and wonderful pomegranate transplants as influenced by the differential investigated bio NPK fertilizers treatments. Herein, Data obtained during both 2017 and 2018 experimental seasons are presented in Table (4). Tabulated data revealed that all investigated treatments resulted significantly in increasing leaves fresh and dry weight of Manfaloty and wonderful pomegranate transplants compared to control. On the other side, T6- RD+ $5 \mathrm{ml}$ of Potasane and $\mathrm{T} 7-\mathrm{RD}+10 \mathrm{ml}$ of Potasane $\left(6^{\text {th }} \& 7^{\text {th }}\right.$ treatments) didn't effect on leaves fresh and dry weight of Manfaloty and wonderful pomegranate transplants. Such a trend was actual during both $2017 \& 2018$ experimental seasons with both cultivars.

However, T8- RD NPK mineral fertilizers + Nitrobene at $5 \mathrm{ml}+$ Phosphorene at $5 \mathrm{ml}+$ Potasene at $5 \mathrm{ml} /$ transplant were statistically the superior. Moreover,T3. RD $+10 \mathrm{ml}$ of Nitrobin ranked statistically $2^{\text {nd }}$, while $\mathrm{T} 2$. RD $+5 \mathrm{ml}$ of Nitrobin came third. Such a trend was actual during both the $2017 \&$ 2018 experimental seasons.

The present results regarding the great beneficence of NPK bio-fertilizers application on stimulating different growth parameters goes in parallel line with those found by several investigators i.e., (EL-Gioushy, 2016) on young Manfalouty Pomegranate trees and (El-Badawy and Ali, Maha, 2019) on Banana Grande Naine Cultivar. 
Table 3. Effect of NPK bio- fertilizers on number of lateral shoot number of main branches/ transplants andnumber of main branches/ transplant during 2017and 2018 experimental seasons.

\begin{tabular}{|c|c|c|c|c|}
\hline \multicolumn{5}{|c|}{ A. Manfaloty pomegranate transplants } \\
\hline \multirow[t]{2}{*}{ Parameters } & \multicolumn{2}{|c|}{$\begin{array}{c}\text { Number of lateral shoots / } \\
\text { transplant }\end{array}$} & \multicolumn{2}{|c|}{$\begin{array}{c}\text { Number of main } \\
\text { branches/ transplant }\end{array}$} \\
\hline & 2017 & 2018 & 2017 & 2018 \\
\hline T1. Control (recommended dose) & $6.000 \mathrm{abc}$ & $6.000 \mathrm{abc}$ & $2.2667 \mathrm{abc}$ & $1.6667 \mathrm{c}$ \\
\hline T2. RD+5ml of Nitrobin & $7.00 \mathrm{ab}$ & $7.33 \mathrm{ab}$ & $2.6607 \mathrm{a}$ & $1.8333 \mathrm{bc}$ \\
\hline T3. RD+10ml of Nitrobin & $8.000 \mathrm{a}$ & $6.6667 \mathrm{ab}$ & $2.500 \mathrm{a}$ & $2.6667 \mathrm{a}$ \\
\hline T4. RD+5ml of Phosphorene & $7.000 \mathrm{ab}$ & $7.00 \mathrm{ab}$ & $1.500 \mathrm{bc}$ & $2.000 \mathrm{bc}$ \\
\hline T5. RD+10ml of Phosphorene & $7.33 \mathrm{ab}$ & $7.667 \mathrm{a}$ & $2.33 \mathrm{ab}$ & $2.333 \mathrm{ab}$ \\
\hline T6. RD+ $5 \mathrm{ml}$ of Potasane & $7.000 \mathrm{bc}$ & $5.000 \mathrm{bc}$ & $1.333 \mathrm{c}$ & $2.1667 \mathrm{abc}$ \\
\hline T7. RD+10ml of Potasane & $6.33 \mathrm{c}$ & $4.000 \mathrm{c}$ & $2.600 \mathrm{abc}$ & $2.000 \mathrm{bc}$ \\
\hline $\begin{array}{l}\text { T8. RD+ } 5 \mathrm{ml} \text { Nitrobin }+5 \mathrm{ml} \text { Phosphorene }+5 \mathrm{ml} \\
\text { of Potasene }\end{array}$ & $8.000 \mathrm{a}$ & $8.000 \mathrm{a}$ & $2.833 \mathrm{a}$ & $2.6667 \mathrm{a}$ \\
\hline \multirow{3}{*}{ Parameters } & pomegranat & ansplants & & \\
\hline & \multicolumn{2}{|c|}{$\begin{array}{l}\text { Number Of Lateral } \\
\text { Shoots / Transplant }\end{array}$} & \multicolumn{2}{|c|}{$\begin{array}{c}\text { Number of main } \\
\text { branches/ transplant }\end{array}$} \\
\hline & 2017 & 2018 & 2017 & 2018 \\
\hline T1. Control (recommended dose) & $7.000 \mathrm{~b}$ & $4.000 \mathrm{~b}$ & $1.8333 \mathrm{c}$ & $2.0833 \mathrm{abc}$ \\
\hline T2. RD+5ml of Nitrobin & $9.000 \mathrm{a}$ & $8.667 \mathrm{a}$ & $2.500 \mathrm{ab}$ & $2.500 \mathrm{ab}$ \\
\hline T3. RD+10ml of Nitrobin & $9.33 \mathrm{a}$ & $8.667 \mathrm{a}$ & $2.6667 \mathrm{a}$ & $2.500 \mathrm{ab}$ \\
\hline T4. RD+5ml of Phosphorene & $8.6667 \mathrm{ab}$ & $6.33 \mathrm{ab}$ & $2.0833 \mathrm{bc}$ & $2.1667 \mathrm{abc}$ \\
\hline T5. RD+10ml of Phosphorene & $8.6667 \mathrm{ab}$ & $7.33 \mathrm{ab}$ & $2.333 \mathrm{ab}$ & $2.5000 \mathrm{ab}$ \\
\hline T6. RD+ $5 \mathrm{ml}$ of Potasane & $9.333 \mathrm{a}$ & $8.000 \mathrm{a}$ & $2.1667 b$ & $2.000 \mathrm{bc}$ \\
\hline T7. RD+10ml of Potasane & $8.333 \mathrm{ab}$ & $7.000 \mathrm{ab}$ & $2.1667 \mathrm{bc}$ & $1.7500 \mathrm{c}$ \\
\hline $\begin{array}{l}\text { T8. RD+ } 5 \mathrm{ml} \text { Nitrobin }+5 \mathrm{ml} \text { Phosphorene }+5 \mathrm{ml} \\
\text { of Potasene }\end{array}$ & $9.000 \mathrm{a}$ & $8.000 \mathrm{a}$ & $2.6667 \mathrm{ab}$ & $2.667 \mathrm{a}$ \\
\hline
\end{tabular}

Means followed by the same letter/s within each column did not significantly differ at $5 \%$ level.

Table 4. Effect of NPK bio- fertilizers on leaves fresh and dry weight (g) during 2017and 2018 experimental seasons.

\begin{tabular}{|c|c|c|c|c|}
\hline \multicolumn{5}{|c|}{ A. Manfaloty pomegranate transplants } \\
\hline \multirow[t]{2}{*}{ Parameters } & \multicolumn{2}{|c|}{ Leaves fresh weight $(\mathrm{g})$} & \multicolumn{2}{|c|}{ Leaves dry weight (g) } \\
\hline & 2017 & 2018 & 2017 & 2018 \\
\hline T1. Control (recommended dose) & $22.00 \mathrm{~d}$ & $17.667 \mathrm{~d}$ & $14.767 \mathrm{~d}$ & $12.533 \mathrm{e}$ \\
\hline T2. RD+5ml of Nitrobin & $24.233 \mathrm{ab}$ & $18.400 \mathrm{c}$ & $15.467 \mathrm{c}$ & $15.833 \mathrm{~b}$ \\
\hline T3. RD+10ml of Nitrobin & $24.500 \mathrm{ab}$ & $19.200 \mathrm{~b}$ & $15.900 \mathrm{~b}$ & $16.200 \mathrm{~b}$ \\
\hline T4. RD+5ml of Phosphorene & $23.70 \mathrm{bc}$ & $16.300 \mathrm{e}$ & $15.867 \mathrm{~b}$ & $13.500 \mathrm{~d}$ \\
\hline T5. RD+10ml of Phosphorene & $23.100 \mathrm{c}$ & $15.400 f$ & $13.900 \mathrm{e}$ & $14.733 \mathrm{c}$ \\
\hline T6. RD+ $5 \mathrm{ml}$ of Potasane & $21.400 \mathrm{~d}$ & $14.633 \mathrm{~g}$ & $10.767 \mathrm{f}$ & $10.767 \mathrm{f}$ \\
\hline T7. RD+10ml of Potasane & $16.70 \mathrm{e}$ & $14.267 \mathrm{~h}$ & $9.700 \mathrm{~g}$ & $10.367 \mathrm{~g}$ \\
\hline $\begin{array}{l}\text { T8. RD+ } 5 \mathrm{ml} \text { Nitrobin }+5 \mathrm{ml} \\
\text { Phosphorene+5ml of Potasene }\end{array}$ & $24.867 \mathrm{a}$ & $19.657 \mathrm{a}$ & $17.733 \mathrm{a}$ & $17.300 \mathrm{a}$ \\
\hline \multicolumn{5}{|c|}{ 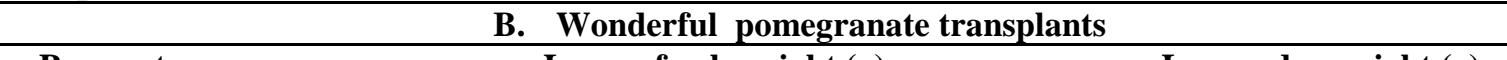 } \\
\hline Parameters & \multicolumn{2}{|c|}{ Leaves fresh weight (g) } & \multicolumn{2}{|c|}{ Leaves dry weight (g) } \\
\hline Treatments & 2017 & 2018 & 2017 & 2018 \\
\hline T1. Control (recommended dose) & $25.167 \mathrm{f}$ & $19.467 \mathrm{~d}$ & $14.300 \mathrm{cb}$ & $16.267 \mathrm{c}$ \\
\hline T2. RD+5ml of Nitrobin & $36.200 \mathrm{c}$ & $19.967 \mathrm{c}$ & $15.200 \mathrm{~b}$ & $17.176 \mathrm{~b}$ \\
\hline T3. RD+10ml of Nitrobin & $37.700 \mathrm{~b}$ & $21.33 \mathrm{a}$ & $17.267 \mathrm{a}$ & $17.433 \mathrm{~b}$ \\
\hline T4. RD+5ml of Phosphorene & $26.200 \mathrm{e}$ & $19.467 \mathrm{~d}$ & $14.400 \mathrm{bc}$ & $15.300 \mathrm{~d}$ \\
\hline T5. RD+10ml of Phosphorene & $30.767 \mathrm{~d}$ & $19.33 \mathrm{~d}$ & $14.367 \mathrm{bc}$ & $14.33 \mathrm{e}$ \\
\hline T6. RD+ $5 \mathrm{ml}$ of Potasane & $23.233 \mathrm{~g}$ & $18.100 \mathrm{e}$ & $13.600 \mathrm{c}$ & $13.567 \mathrm{f}$ \\
\hline T7. RD+10ml of Potasane & $17.267 \mathrm{~h}$ & $16.833 \mathrm{f}$ & $11.200 \mathrm{~d}$ & $10.167 \mathrm{~g}$ \\
\hline $\begin{array}{l}\text { T8. RD+ } 5 \mathrm{ml} \text { Nitrobin }+5 \mathrm{ml} \\
\text { Phosphorene+5ml of Potasene }\end{array}$ & $39.200 \mathrm{a}$ & $21.700 \mathrm{a}$ & $18.200 \mathrm{a}$ & $18.600 \mathrm{a}$ \\
\hline
\end{tabular}

Means followed by the same letter/s within each column did not significantly differ at $5 \%$ level. 
4 -Effect of NPK bio- fertilizers on leaf area (cm2) and number of leaves of Manfaloty and wonderful pomegranate transplants:

In this regard leaf area $(\mathrm{cm} 2)$ and number of leaves of Manfaloty and wonderful pomegranate transplants as influenced by the differential investigated treatments. Herein, Data obtained during 2017 \& 2018 experimental seasons are presented in Table (5). Tabulated data revealed that all investigated treatments resulted significantly in increasing leaf area $\left(\mathrm{cm}^{2}\right)$ and number of leaves of Manfaloty and wonderful pomegranate transplants as compared to control. On the other side, T6- RD+ $5 \mathrm{ml}$ of Potasane and T7- RD+10ml of Potasane $\left(6^{\text {th }} \& 7^{\text {th }}\right.$ treatments $)$ didn't effect on leaf area $(\mathrm{cm} 2)$ and number of leaves of Manfaloty and wonderful pomegranate transplants. However, T8- RD NPK mineral fertilizers + Nitrobene at $5 \mathrm{ml}+$ Phosphorene at $5 \mathrm{ml}+$ Potasene at $5 \mathrm{ml} /$ transplant were statistically the superior . Moreover, T3. RD $+10 \mathrm{ml}$ of Nitrobin ranked statistically $2^{\text {nd }}$, while $T 2$. $\mathrm{RD}+5 \mathrm{ml}$ of Nitrobin came third. Such a trend was actual during both the 2017 \& 2018 experimental seasons.On the contrary, the least values of the abovementioned parameters were usually in concomitant to $\mathrm{T}_{1}$ - Control (recommended dose) which ranked statistically last during both seasons of study. Besides, the other investigated were in between the previously mentioned two extremes.

Table 5. Effect of NPK bio- fertilizers on leaf area $\left(\mathrm{cm}^{2}\right)$ and number of leaves during 2017 and 2018 experimental seasons.

A. Manfaloty pomegranate transplants

\begin{tabular}{|c|c|c|c|c|}
\hline \multicolumn{5}{|c|}{ A. Manfaloty pomegranate transplants } \\
\hline \multirow[t]{2}{*}{ Parameters } & \multicolumn{2}{|c|}{ Leaf area $(\mathrm{cm} 2)$} & \multicolumn{2}{|c|}{ Number of leaves } \\
\hline & 2017 & 2018 & 2017 & 2018 \\
\hline T1. Control (recommended dose) & $4.833 \mathrm{~d}$ & $3.7667 \mathrm{c}$ & $118.67 \mathrm{e}$ & $114.67 \mathrm{e}$ \\
\hline T2. RD+5ml of Nitrobin & $5.833 \mathrm{~b}$ & $4.200 \mathrm{~b}$ & $181.67 \mathrm{a}$ & $130.67 \mathrm{c}$ \\
\hline T3. RD+10ml of Nitrobin & $6.200 \mathrm{a}$ & $4.200 \mathrm{~b}$ & $182.00 \mathrm{a}$ & $138.00 \mathrm{~b}$ \\
\hline T4. RD+5ml of Phosphorene & $5.200 \mathrm{c}$ & $4.100 \mathrm{~b}$ & $160.0 \mathrm{c}$ & $121.33 \mathrm{~d}$ \\
\hline T5. RD+10ml of Phosphorene & $5.3667 \mathrm{c}$ & $3.553 \mathrm{~d}$ & $172.67 \mathrm{~b}$ & $123.00 \mathrm{~d}$ \\
\hline T6. RD+ 5ml of Potasane & $4.4667 \mathrm{e}$ & $3.800 \mathrm{c}$ & $134.67 \mathrm{~d}$ & $112.67 \mathrm{e}$ \\
\hline T7. RD+10ml of Potasane & $3.867 \mathrm{f}$ & $3.900 \mathrm{c}$ & $118.67 \mathrm{e}$ & $104.33 \mathrm{f}$ \\
\hline T8. RD+ 5ml Nitrobin $+5 \mathrm{ml}$ & $6.733 \mathrm{a}$ & $6.00 \mathrm{a}$ & $184.33 \mathrm{a}$ & $150.33 \mathrm{a}$ \\
\hline \multicolumn{5}{|l|}{ Phosphorene $+5 \mathrm{ml}$ of Potasene } \\
\hline & Wonderfu & ranate tr: & & \\
\hline \multirow[t]{2}{*}{ Parameters } & \multicolumn{2}{|c|}{ Leaf area $(\mathrm{cm} 2)$} & \multicolumn{2}{|c|}{ Number of leaves } \\
\hline & 2017 & 2018 & 2017 & 2018 \\
\hline $\begin{array}{l}\text { T1. Control (recommended } \\
\text { dose) }\end{array}$ & $4.700 \mathrm{~cd}$ & $5.167 \mathrm{c}$ & $222.00 \mathrm{~d}$ & $130.67 \mathrm{~d}$ \\
\hline T2. RD+5ml of Nitrobin & $5.200 \mathrm{~b}$ & $5.600 \mathrm{~b}$ & $243.33 \mathrm{~b}$ & $145.67 \mathrm{c}$ \\
\hline T3. RD+10ml of Nitrobin & $5.233 \mathrm{~b}$ & $5.833 \mathrm{~b}$ & $259.00 \mathrm{a}$ & $182.33 \mathrm{~b}$ \\
\hline T4. RD+5ml of Phosphorene & $4.900 \mathrm{c}$ & $4.700 \mathrm{~d}$ & $215.00 \mathrm{e}$ & $144.33 \mathrm{c}$ \\
\hline T5. RD+10ml of Phosphorene & $4.733 \mathrm{~cd}$ & $4.900 \mathrm{~d}$ & $226.67 \mathrm{c}$ & $131.67 \mathrm{~d}$ \\
\hline T6. RD+ $5 \mathrm{ml}$ of Potasane & $4.600 \mathrm{~d}$ & $3.800 \mathrm{e}$ & $191.33 \mathrm{f}$ & $120.00 \mathrm{e}$ \\
\hline T7. RD+10ml of Potasane & $4.300 \mathrm{e}$ & $3.733 \mathrm{e}$ & $145.67 \mathrm{~g}$ & $115.00 \mathrm{e}$ \\
\hline $\begin{array}{l}\text { T8. RD+ } 5 \mathrm{ml} \text { Nitrobin }+5 \mathrm{ml} \\
\text { Phosphorene }+5 \mathrm{ml} \text { of Potasene }\end{array}$ & $6.600 \mathrm{a}$ & $6.467 \mathrm{a}$ & $261.33 \mathrm{a}$ & $191.33 \mathrm{a}$ \\
\hline
\end{tabular}

Means followed by the same letter/s within each column did not significantly differ at 5\% level.

5 -Effect of NPK bio- fertilizers on stem fresh and dry weight(g) of Manfaloty and wonderful pomegranate transplants:

Table (6) displays obviously that seven investigated treatments increased the stem fresh and dry weight $(\mathrm{g})$ of Manfaloty and wonderful pomegranate transplants over $\mathrm{T} 1 \quad-$ control (recommended doses) significantly. However, T8RD NPK mineral fertilizers + Nitrobene at $5 \mathrm{ml}+$ Phosphorene at $5 \mathrm{ml}+$ Potasene at $5 \mathrm{ml} /$ transplant were statistically the superior in this concern during both 2017 \& 2018 experimental seasons. However, $3^{\text {rd }}$ treatment (RD $+10 \mathrm{ml}$ of Nitrobin / transplant) ranked statistically second, descendingly followed by $\mathrm{T} 2-\mathrm{RD}+5 \mathrm{ml}$ of Nitrobin and T7. RD+10ml of
Potasane per transplant during both experimental seasons. On the contrary, the least values of the abovementioned parameters were usually in concomitant to $\mathrm{T}_{1}$ - Control (recommended dose) which ranked statistically last during both seasons of study. Besides, the other investigated were in between the previously mentioned two extremes.

This result may be attributed to the relatively higher uptake of more accessible $\mathrm{N}$ form could be absorbed and/or translocated within tissues as a direct result of applying such $\mathrm{N}$ more productive compounds where an adequate and sufficient $\mathrm{N}$ level is needed at such critical stage of plant development.

The obtained result regarding the positive effect exhibited by differential treatments goes in line with 
those found byBaiea and EL-Gioushy, onbanana cv. Grande Naine plants, (2015), EL-Gioushy, (2016) on Young Manfalouty Pomegranate TreesEl-
Badawy et al., (2017) on Washington Navel Orange trees and Salama et al., (2017) on Washington Navel Orange Trees.

Table 6. Effect of NPK bio- fertilizers on stem fresh and dry weight(g) during 2017and 2018 experimental seasons.

\begin{tabular}{|c|c|c|c|c|}
\hline \multicolumn{5}{|c|}{ A. Manfaloty pomegranate transplants } \\
\hline \multirow[t]{2}{*}{ Parameters } & \multicolumn{2}{|c|}{ Stem Fresh Weight (g) } & \multirow[b]{2}{*}{2017} & \multirow[b]{2}{*}{2018} \\
\hline & 2017 & 2018 & & \\
\hline T1. Control (recommended dose) & $45.267 \mathrm{e}$ & $54.100 \mathrm{e}$ & $23.300 \mathrm{f}$ & $32.233 \mathrm{c}$ \\
\hline T2. RD+5ml of Nitrobin & $55.833 \mathrm{c}$ & $55.933 \mathrm{c}$ & $29.300 \mathrm{c}$ & $36.233 \mathrm{a}$ \\
\hline T3. RD+10ml of Nitrobin & $56.967 \mathrm{~b}$ & $63.667 \mathrm{~b}$ & $30.067 \mathrm{~b}$ & $36.300 \mathrm{a}$ \\
\hline T4. RD+5ml of Phosphorene & $48.700 \mathrm{~d}$ & $55.130 \mathrm{~d}$ & $27.333 \mathrm{~d}$ & $34.067 \mathrm{bc}$ \\
\hline T5. RD+10ml of Phosphorene & $54.933 \mathrm{c}$ & $55.00 \mathrm{~d}$ & $24.333 \mathrm{e}$ & $35.533 \mathrm{ab}$ \\
\hline T6. RD+ $5 \mathrm{ml}$ of Potasane & $44.900 \mathrm{e}$ & $46.800 \mathrm{f}$ & $22.667 \mathrm{~g}$ & $32.233 \mathrm{c}$ \\
\hline T7. RD+10ml of Potasane & $37.633 \mathrm{f}$ & $45.133 \mathrm{~g}$ & $20.433 \mathrm{~h}$ & $25.33 \mathrm{~d}$ \\
\hline \multicolumn{5}{|l|}{ Phosphorene $+5 \mathrm{ml}$ of Potasene } \\
\hline \multicolumn{5}{|c|}{ B. Wonderful pomegranate transplants } \\
\hline \multirow[t]{2}{*}{ Parameters } & \multicolumn{2}{|c|}{ Stem freh weight $(\mathrm{g})$} & \multicolumn{2}{|c|}{ Stem Dry Weight (G) } \\
\hline & 2017 & 2018 & 2017 & 2018 \\
\hline T1. Control (recommended dose) & $45.867 \mathrm{~d}$ & $59.267 \mathrm{bc}$ & $31.733 \mathrm{~d}$ & $23.700 \mathrm{e}$ \\
\hline T2. RD+5ml of Nitrobin & $87.267 \mathrm{a}$ & $74.133 \mathrm{a}$ & $36.400 \mathrm{ab}$ & $32.500 \mathrm{~b}$ \\
\hline T3. RD+10ml of Nitrobin & $87.367 \mathrm{a}$ & $74.533 \mathrm{a}$ & $37.267 \mathrm{a}$ & $33.133 \mathrm{~b}$ \\
\hline T4. RD+5ml of Phosphorene & $64.133 \mathrm{~b}$ & $62.367 \mathrm{~b}$ & $35.133 \mathrm{bc}$ & $25.767 \mathrm{~d}$ \\
\hline T5. RD+10ml of Phosphorene & $60.333 \mathrm{c}$ & $57.000 \mathrm{bcd}$ & $33.367 \mathrm{~cd}$ & $31.167 \mathrm{c}$ \\
\hline T6. RD+ $5 \mathrm{ml}$ of Potasane & $43.5674 \mathrm{e}$ & $54.700 \mathrm{bc}$ & $27.233 \mathrm{e}$ & $16.167 \mathrm{f}$ \\
\hline T7. RD+10ml of Potasane & $26.500 \mathrm{f}$ & $51.833 \mathrm{~d}$ & $19.500 \mathrm{f}$ & $14.800 \mathrm{~g}$ \\
\hline $\begin{array}{l}\text { T8. RD+ } 5 \mathrm{ml} \text { Nitrobin }+5 \mathrm{ml} \\
\text { Phosphorene }+5 \mathrm{ml} \text { of Potasene }\end{array}$ & $87.900 \mathrm{a}$ & $74.533 \mathrm{a}$ & $37.500 \mathrm{a}$ & $36.367 \mathrm{a}$ \\
\hline
\end{tabular}

Means followed by the same letter/s within each column did not significantly differ at $5 \%$ level.

5 -Effect of NPK bio- fertilizers on root weight (g) and root length $(\mathrm{cm})$ of Manfaloty and wonderful pomegranate transplants:

In this regard root weight and root length $(\mathrm{cm})$ were the two investigated roots properties for Manfaloty and wonderful pomegranate transplants regarding their response to the differential treatments . Data obtained during both 2017 \& 2018 experimental seasons are presented in Table (6). Herein, It is quite clear that the response of root weight and root length to the differential investigated treatments followed to great extent the same trend previously detected with leaves properties. Hence, $\mathrm{T}_{8}$ and $\mathrm{T}_{3}$ i.e., (RD NPK mineral fertilizers + Nitrobene at $5 \mathrm{ml}+$ Phosphorene at $5 \mathrm{ml}+$ Potasene at $5 \mathrm{ml} /$ transplant) and (RD+10ml of Nitrobin), respectively were statistically the most effective and showed significantly the same level root properties for Manfaloty and wonderful pomegranate transplants. during both experimental seasons. The reverse was true with $\mathrm{T}_{1}$ - Control (recommended dose) that induced significantly the poorest transplants roots properties during both seasons. besides, other investigated treatments were in between the abovementioned two extremes.

The present result goes partially in the line with that pointed out by several investigators regarding the beneficial effect of differential fertilizers on improving roots properties i.e., El-Gioushy and Baiea (2015) on Canino Apricot,Abd-El-Latif et al., (2017) on "Le-Conte" pear trees and Salama et al., (2017) on Washington Navel Orange Trees.

Table 7. Effect of NPK bio- fertilizers on root weight (g) and root length (cm) during 2017 and 2018 experimental seasons.

A. Manfaloty pomegranate transplants

\begin{tabular}{|c|c|c|c|c|}
\hline \multirow[t]{2}{*}{ Parameters } & \multicolumn{2}{|c|}{ Root weight (g) } & \multicolumn{2}{|c|}{ Root Length $(\mathbf{C m})$} \\
\hline & 2017 & 2018 & 2017 & 2018 \\
\hline T1. Control (recommended dose) & $11.833 \mathrm{bcd}$ & $12.000 \mathrm{~cd}$ & $13.667 \mathrm{bcd}$ & $10.667 \mathrm{c}$ \\
\hline T2. RD+5ml of Nitrobin & $12.967 \mathrm{ab}$ & $13.133 \mathrm{abc}$ & $16.000 \mathrm{ab}$ & $15.000 \mathrm{~b}$ \\
\hline T3. RD+10ml of Nitrobin & $13.167 \mathrm{ab}$ & $13.233 \mathrm{ab}$ & $16.667 \mathrm{ab}$ & $17.00 \mathrm{ab}$ \\
\hline T4. RD+5ml of Phosphorene & $12.250 \mathrm{bcd}$ & $12.667 \mathrm{bcd}$ & $12.333 \mathrm{~cd}$ & $11.667 \mathrm{c}$ \\
\hline T5. RD+10ml of Phosphorene & $12.333 \mathrm{bc}$ & $12.467 \mathrm{~d}$ & $14.667 \mathrm{bc}$ & $10.667 \mathrm{c}$ \\
\hline
\end{tabular}




\begin{tabular}{|c|c|c|c|c|}
\hline T6. RD+ $5 \mathrm{ml}$ of Potasane & $11.483 \mathrm{~cd}$ & $11.667 \mathrm{de}$ & $11.00 \mathrm{~d}$ & $9.000 \mathrm{~cd}$ \\
\hline T7. RD+10ml of Potasane & $10.833 \mathrm{~d}$ & $10.583 \mathrm{e}$ & $7.000 \mathrm{e}$ & $7.667 \mathrm{~d}$ \\
\hline T8. RD+ 5ml Nitrobin $+5 \mathrm{ml}$ & $14.000 \mathrm{a}$ & $14.00 \mathrm{a}$ & $18.000 \mathrm{a}$ & $18.00 \mathrm{a}$ \\
\hline Phosphorene $+5 \mathrm{ml}$ of Potasene & & & & \\
\hline \multicolumn{5}{|c|}{ B. Wonderful pomegranate transplants } \\
\hline \multirow[t]{2}{*}{ Parameters } & \multicolumn{2}{|c|}{ Root weight (g) } & \multicolumn{2}{|c|}{ Root Length $(\mathrm{Cm})$} \\
\hline & 2017 & 2018 & 2017 & 2018 \\
\hline T1. Control (recommended dose) & $20.467 \mathrm{bc}$ & $19.500 \mathrm{~b}$ & $10.500 \mathrm{~b}$ & $11.667 \mathrm{abc}$ \\
\hline T2. RD+5ml of Nitrobin & $22.167 \mathrm{abc}$ & $19.967 \mathrm{~b}$ & $13.00 \mathrm{ab}$ & $12.667 \mathrm{abc}$ \\
\hline T3. RD+10ml of Nitrobin & $23.756 \mathrm{ab}$ & $23.00 \mathrm{a}$ & $13.00 \mathrm{ab}$ & $13.33 \mathrm{ab}$ \\
\hline T4. RD+5ml of Phosphorene & $18.600 \mathrm{c}$ & $19.33 \mathrm{~b}$ & $10.33 \mathrm{~b}$ & $11.167 \mathrm{abc}$ \\
\hline T5. RD+10ml of Phosphorene & $19.500 \mathrm{c}$ & $19.400 \mathrm{~b}$ & $11.00 \mathrm{ab}$ & $12.00 \mathrm{abc}$ \\
\hline T6. RD+ $5 \mathrm{ml}$ of Potasane & $11.833 \mathrm{~d}$ & $17.00 \mathrm{c}$ & $10.00 \mathrm{~b}$ & $10.00 \mathrm{c}$ \\
\hline T7. RD+10ml of Potasane & $14.500 \mathrm{~d}$ & $19.300 \mathrm{~b}$ & $10.00 \mathrm{~b}$ & $11.00 \mathrm{bc}$ \\
\hline T8. $R D+5 \mathrm{ml}$ Nitrobin $+5 \mathrm{ml}$ & $26.00 \mathrm{a}$ & $23.567 \mathrm{a}$ & $14.00 \mathrm{a}$ & $14.33 \mathrm{a}$ \\
\hline Phosphorene $+5 \mathrm{ml}$ of Potasene & & & & \\
\hline
\end{tabular}

Means followed by the same letter/s within each column did not significantly differ at $5 \%$ level.

\section{Conclusion}

Conclusively, from the obtained results, it can be concluded that using of recommended doses of NPK mineral fertilizers + Nitrobene at $5 \mathrm{ml}+$ Phosphorene at $5 \mathrm{ml}+$ Potasene at $5 \mathrm{ml}$ per transplantcould be safely recommended, as their beneficial effects on different growth parameters of Manfaloty and wonderful pomegranate transplants grown under similar environmental conditions and horticulture practices adopted in present experiment.

\section{References}

According to the yearly Bull. Agric. Economic and Statistics Ministry of Agriculture and Land Reclamation of Egypt (2014).

A.O.A.C. Association of Official Agricultural Chemists (1985): Official Methods of Analysis A.O.A.C. Benjamin Franklin Station, Washington D.C., U.S.A., p 440-512.

Abd-elghany, N.A., Nasr, S.I. and Korkar, H.M. (2012): Effects of polyolefin film wrapping and calcium chloride treatments on post-harvest quality of "Wonderful" pomegranate fruits. Journal of Horticultural Science \& Ornamental Plants, 4 (1), 7-17.

Abd-El-Latif, F.M., El-Gioushy, S.F., Ismail, A.F. and Mohamed, M.S. (2017). The impact of biofertilization, plant extracts and potassium silicate on some fruiting aspects and fruit quality of "LeConte" pear trees. Middle East Journal of Applied Sciences. 7(2): 385-397.

Abo-El-Ez, A. T.; Mostafa, R. A. A. and Badawy, Ibtesam F. M. (2013): Growth and productivity of three Fig (Ficus carica L.) cultivars grown under Upper Egypt conditions. Australian Journal of Basic and Applied Sciences, 7(2): 709-714.

Abo-Taleb, Safia, A.; L. H. Osman and N. F. Youssef (1999). Effect of soil application of active dry yeast (Saccharomyces cereivisae) on growth and fruiting in pomegranate trees. Minufiya J. Agric. Res. 24 (1): 289-304.

Afify, A. M. E. (2006): Evaluationof some fig cultivars cultivated in Egypt. M. Sc. Thesis, Fac. Agric. Benha Univ.

Anonymous (2011). Year book of statistics of Ministry of Agriculture. (Agricultural Economical and Statistical Department, Arab Republic of Egypt: Cairo) [In Arabic].

Aseri, G. K.; N. Jain; J. Panwar; A. V. Rao and P. R. Meghwal (2008). Bio-fertilizers improve plant growth, fruit yield, nutrition, metabolism and rhizosphere enzyme activities of pomegranate (Punica granatum L.) in Indian Thar Desert. Scientia Horticulture 117: 130-135.

Baiea, M.H.M., EL-Gioushy, S. F. and ElSharony, T. F. (2015). Effect of Feldspar and Bio- Fertilization on Growth, Productivity and Fruit Quality of Banana cv. Grande Naine. International Journal of Environment.4 (4): 210218.

Bailey, L. H. (1961): Manual of cultivated plants. The Macmillan Company, New Yourk, pp. 116.

Berg, C. C. (2003): "Flora malesiana precursor for the treatment of Moraceae 1: The main subdivision of Ficus: the subgenera," Blumea, 48 (1):167-178.

Brison, F. P. (1974): Pecan culture, capital printing, Austin texas, USA pp. 27-255.

Chapman, H. D. and Pratt, P. F. (1961): Methods of Analysis for Soil, Plant and Waters. Univ. of California Division of Agric. Sci. 6th Ed. Pi 5664.

Darwish, D. R. A (2012): Physiological studies on persimmon "Diospyros kaki" trees. Ph.D. Thesis, Fac. Agric., Benha. Univ.

Duncan, D. B. (1955): Multiple ranges and multiple F. test. Biometrics,11: 1-42.

Ebrahiem, T. A. and G. A. Mohamed (2000): Response of Balady mandarin trees growing on sandy soil to application of filter mud and 
farmyard manure. Assiut Jour. of Agric. Sci. 31 (5): 55-69.

El-Badawy H. E. M, El-Gioushy S. F., Baiea M. H. M, and EL-Khwaga, A. A. (2017). Effect of Some Antioxidants and Nutrients Treatments on Vegetative Growth and Nutritional Status of Washington Navel Orange Trees. Middle East Journal of Agriculture Research. 6(1): 87-98.

El-Badawy, H. E. M. and Ali, Maha M. E. (2019): Effect of Some Fertilization Treatments on Growth, Yield, Fruit Quality and Nutritional Status of Banana Grande Naine Cultivar.Annals of Agric. Sci., Moshtohor, 57 (1):89-98.

EL-Gioushy, S. F. (2016): Comparative study on the NPK fertilization sources of young Manfalouty Pomegranate trees.J. Plant Production, Mansoura Univ., 7 (10): 1037 - 1042.

EL-Gioushy, S. F. and Baiea, M. H. M. (2015). Partial Substitution of Chemical Fertilization of Canino Apricot by Bio and Organic Fertilization. Middle East Journal of Applied Sciences. 5(4): 823-832.

EL-Gioushy, S.F., Abedelkhalek, A. and Abdelaziz, A.M.R.A. (2018). Partial Replacement of Mineral NPK by Organic and Bio-Fertilizers of Fagri Kalan Mango Trees. Journal of Horticultural Science \& Ornamental Plants 10 (3): 110-117.

El-Ray, R. and Llacer, G. (1995):Cahiers Options Mediterraneennes, 13: 79-83.

El-Sayed, A. (2005): Effect of foliar application of liquid organic fertilizer and/or GA3 in fruiting and leaf mineral composition of Washington Navel orange trees. J. Agric. Res., Zagazig Univ., 32 (4):763-775.

FAO (2013). FAO Statistics Division. Faostat.Org.

FAO. (2006): Agricultural data. FAOSTA'I' faostat.fao.org/faostat/

Follet, R.; Donahue, R. and Murphy, L. (1981). Soil and Soil Amendments. Prentice. Hall, Inc., New Jersey.

Frederickson, J.; Butt, K. R.; Morris, M. R. and Daniel, C. (1997). Combining vermiculture with green waste composting system. Soil. Biol. Biochem., 29 (3/4), 725.730.

Garcia, C.; Hernandez, T.; Costa, F. and Ceccanti, B. (1994). Biochemical parameters in soil regenerated by addition of organic wastes. Waste. Manag. Res, 12: 457-466.

Jackson, M. L. and Ulrich, A. (1967): Analytical Methods for Use in Plant Analysis. Coll. Of Agric. Exp. State Bull. 766.

Jackson, M.L. (1967). Soil Chemical Analysis. Prentice Hall. Inc. Englewood Cliffs., N. J, p.331.

Khanizadeh, S.; C. Hamell H. Kianmehr; D. Buszard and D.L. Smith (1995): Effect of three arbuscular mycorrhizal fungus species and phosphorus on productivity and vegetative growth of three strawberry cultivars. J. Plant Nutr. 18: 1073-1079.
Mohsen, A. M., El- Mosallamy, H. M. and ElHefnawy, S. M. (1987). Some anatomical features of guava seedlings in response to soil moisture and soil salinity. 1. Leaf sbucture . Zagazig J. Agric. Res. No. 14 (1) : 1-22.

Motskobili, N. A. (1984). Assimilation area of Satsuma in relation to mineral nutrition and it's effect on productivity. Subtropicheskie Kultry, No. 5, 83-90 VNILL chayaisk, Makharadze, Georgian SSR. (C.F. Hort., Abst. 55:2979).

Murphy, J. and Riely, J. P. (1962): A modified single method for the determination of phosphorus in natural water. Anal. Chemi. Acta., 27:31-36.

Nijjar, G. S. (1985): Nutrition of Fruit Trees. Mrs. Usha Raji Kumar, Kilyani, New Delhi, India, 206-234.

Osman, S. M. and Abd El-Rhman, I. E. (2010). Effect of Organic and Bio N-fertilization on Growth, Productivity of Fig Tree (Ficus Carica, L.). Research J. of Agric. and Biological Sci., 6 (3): 3195-328.

Palou, L., Carlos, H., Aguilar G. and David G., (2007). Combination of postharvest antifungal chemical treatments and controlled atmosphere storage to control gray mold and improve storability

Pascual, J. A.; Hernandez, T.; Ayuso, M. and Garcia, C. (1997). Changes in the microbial activity of arid soils amended with urban organic wastes. Biol Fert Soils, 24: 429-434.

Pregl, E. (1945): Quantitative Organic Micro Analysis. $4^{\text {th }}$ Ed. Chundril, London.

Rivero, C.; Chirenje, T.; Ma, L. Q. and Martinez,G. (2004). Influence of compost on soil organic matter quality under tropical conditions. Geoderma, 123: 355-361.

Ryckeboer, J.; Mergaert, J.; Vaes, K.; Klammer, S.; De Clercq, D.; Coosemans, J.; Insam, H. and Swings, J. (2003). A survey of bacteria and fungi occurring during composting and selfheating processes. Ann Microbiol, 53: 349-410.

Saha, S.; Mina, B. L.; Gopinath, K. L.; Kundu, S. and Gupta, H. S. (2008). Relative changes in phosphatase activities as influenced by source and application rate of organic composts in field crops. Biores Technol., 99:1750-1757.

Salama, M. I., Sayed, R. A., El-Shereif, A. R. and M. A. Mankolah (2017). Response of Washington Navel Orange Trees to Some Soil Amendments and Foliar application of GA3 under Clay Soil Conditions. J. Sus. Agric. Sci. Vol. 43, No.1, pp. 39-54.

Saric, M.; Kastroi, R.; Curi, R. and Geric, L. (1967): Effect of salinity on some citrus rootstocks. ParkFiziol.Anjiga.pp.215.

Snedecor, G. W. and W. G. Cochran (1977): Statistical Methods 7th Ed. The Iowa State Univ. Press, Ames. 
Subba- Rao, N.S., (1984). Biofertilizers in Agriculture; Oxford IBH, company New Delhi, pp: 1-786.

Subba-Rao, N.S., G.S. Venkateraman and S. Kannaiyan (1993). Biological nitrogen fixation. Indian Council. Agric. Res. New Delhi, p. 112.

The Standard Cyclopedia of Horticulture. Cited After Aly, M.M., M.Sc. Thesis, 1970.

Tutin, T.G. (1964): Flora Europaea, Vol. 2, Cambridge University Press, London.
Wadee, M. Z. (2007). Effect of some bio-fertilizers application on flowering, yield and fruit quality of Manfalouty pomegranate. M.Sc. Thesis, Faculty of Agric., Assiut Univ., Egypt.

Zayan, M.A., Sayed, R.A., El-Shereif, A.R. and El-Zawily, H.M.A. (2016). Irrigation and fertilization programs for "Washington Navel" orange trees in sandy soil under desert climatic conditions. 1-Effect on soil properties, vegetative growth and yield. J. Agric. Res., Kafrelsheikh Univ., 42 (2), 244-267.

\footnotetext{
تأثير أضافة الأسمدة الحيوية (النيتروجينية والفوسفاتية والبوتاسية) علي بعض قياسات النمو لشتلات الرمان المنفلوطي والوندرفول

* رحاب ايهاب بكر الخولي و *أحمد أحمد رزق السيد عطوية و** تامر محمد العقاد و* شريف فتحي عيد السيد الجيوشي * قسم البساتين **قسم الوراثة - كلية الزراعة بمشتهر جامعة بنها مصر.

اجريت هذه التجربة خلال موسمين منتاليين 2017 و 2018 في مشتل الفاكهة بقسم البساتين - كلية الزراعة - بمشتهر - جامعة بنها- محافظة القليوبية- مصر وذلك لدراسة تأثير أضافة التسميد الحيوي من NPK علي بعض قياسات النمو في كلا من الرمان المنفلوطي والوندرفول خلال موسمي الدراسة وعلية كانت المعاملات كالتالي: 1. المعاملة الاولي : الجرعة الموصي بها من قبل وزارة تازراعة من التسميد المعني 2. المعاملة الثانية : الجرعة الموصي بها من التسميد المعدني + 5ملي من النيتروبين مضافا اضافة ارضية لكل شتلة 3. المعاملة الثالثة :الجرعة الموصي بها +10ملي من النيتروبين مضافا اضافة ارضية لكل شتلة 4. المعاملة الرابعة : الجرعة الموصي بها من التسميد المعدني + 5ملي من الفوسفورين مضافا اضافة ارضية لكل شتلة 5. المعاملة الخامسة : الجرعة الموصي بها من التسميد المعدني + 10ملي من الفوسفورين مضافا اضافة ارضية لكل شتلة 6. المعاملة السادسة : الجرعة الموصي بها من التسميد المعدني + 5ملي من البوتاسين مضافا اضافة ارضية لكل شتلة 7. المعاملة السابعة : الجرعة الموصي بها من التسميد المعدني + 10ملي من البوتاسين مضافا اضافة ارضية لكل شتلة 8. المعاملة الثامنة : الجرعة الموصي بها من التسميد المعدني +ملي من النيتروبين +5ملي من الفوسفورين+5ملي من البوتاسين أدي استخدام هذه المعاملات الي زيادة ملحوظة في كلا من طول وقطر الثتلات وكذللك زيادة المساحة الورقية والوزن الطازج والجاف وذلك مقارنة بالكونترول

تفوقت المعاملة الثامنة من الناحية الاحصائية واعطت اعلي القيم في معظم القياسات المدروسة يليها المعاملة الثالثة في كلا الصنفين وذلك خلال موسمي الدراسة وعلي العكس من ذلك أعطت المعاملة الاولي اقل القيم في معظم القياسات المدروسة في كلا الصنفين وذلك خلال موسمي الدراسة واحنلت المرنبة الاخيرة احصائيا خلال موسمي الدراسة.
} 